seasonal variation in exposure to sunlight, more definite in temperate climates, brings about a seasonal fluctuation in serum concentrations of $25(\mathrm{OH}) \mathrm{D}_{3} .^{34}$

$25(\mathrm{OH}) \mathrm{D}_{3}$ is considerably more active than vitamin $\mathrm{D}_{3}$ itself in promoting absorption of calcium from the gut, but it is not the final active metabolite. ${ }^{2}$ Further metabolism takes place in the kidney, where the dihydroxylated metabolites $1,25(\mathrm{OH})_{2} \mathrm{D}_{3}$ and $24,25(\mathrm{OH})_{2} \mathrm{D}_{3}$ are synthesised. $^{356} 1,25(\mathrm{OH})_{2} \mathrm{D}_{3}$ is produced by an enzyme, $25(\mathrm{OH})_{2} \mathrm{D}_{3}$-1-hydroxylase, in the renal proximal tubular cells ${ }^{7}$; this enzyme is inhibited by hypercalcaemia, hyperphosphataemia, low serum concentrations of parathyroid hormone, vitamin $\mathrm{D}$ repletion, and by $1,25(\mathrm{OH})_{2} \mathrm{D}_{3}$ itself. $^{28}$ Synthesis of $1,25(\mathrm{OH})_{2} \mathrm{D}_{3}$ is stimulated by hypocalcaemia, hypophosphataemia, high serum concentrations of parathyroid hormone, vitamin $\mathrm{D}$ depletion, and $24,25(\mathrm{OH})_{2} \mathrm{D}_{3}{ }^{89}$

$24,25(\mathrm{OH})_{2} \mathrm{D}_{3}$ is produced by a similar enzyme, $25(\mathrm{OH}) \mathrm{D}_{3}$-24-hydroxylase, again found in the renal proximal tubular cells ${ }^{10}$; this enzyme is inhibited by hypocalcaemia, hypophosphataemia, high serum concentrations of parathyroid hormone, vitamin $\mathrm{D}$ depletion, and $1,25(\mathrm{OH})_{2} \mathrm{D}_{3} .{ }^{811}$ Thus in normal people replete with vitamin $\mathrm{D}, 24,25(\mathrm{OH})_{2} \mathrm{D}_{3}$ is the major circulating dihydroxylated metabolite of vitamin $\mathrm{D}_{3}$. At times of vitamin $\mathrm{D}$ deficiency production of $1,25(\mathrm{OH})_{2} \mathrm{D}_{3}$ is increased as an adaptive measure aimed at maintaining a normal serum calcium concentration by mobilising calcium from gut and bone. ${ }^{8}$

Against this background not surprisingly renal failure has potentially serious effects on the production of active metabolites of vitamin $\mathrm{D}$. When the glomerular filtration rate falls below $25-30 \mathrm{ml}$ a minute the serum concentration of $1,25(\mathrm{OH})_{2} \mathrm{D}_{3}$ often falls substantially owing to a combination of a reduced mass of functioning nephrons and inhibition of $25(\mathrm{OH}) \mathrm{D}_{3}-1$-hydroxylase by the hyperphosphataemia that commonly accompanies renal insufficiency. In end stage renal failure and in patients undergoing dialysis, serum concentrations of $25(\mathrm{OH}) \mathrm{D}_{3}$ are variable ${ }^{412}$ and of $1,25(\mathrm{OH})_{2} \mathrm{D}_{3}$ and $24,25(\mathrm{OH})_{2} \mathrm{D}_{3}$ uniformly low. ${ }^{1314}$ Patients in renal failure of this severity often have histological evidence of a defect of mineralisation. ${ }^{15}$ Osteomalacia is not, however, invariable-and indeed is uncommon in patients having dialysis who are replete with vitamin $D$. Improvement of the mineralisation defect has been observed after the start of dialysis even in an anephric patient not treated with vitamin $\mathrm{D} .{ }^{16}$ Although some investigators have found increases in the serum concentration of $25(\mathrm{OH}) \mathrm{D}_{3}$ after the start of dialysis, there is no generally accepted explanation for this apparently spontaneous histological improvement and for the absence of osteomalacia in bone obtained from some anephric patients. ${ }^{4}$

Recently, however, several investigators have reported low but detectable concentrations of the dihydroxylated metabolites of vitamin $D$ in sera from anephric patients with normal or raised serum concentrations of $25(\mathrm{OH}) \mathrm{D}_{3}$. Initially these observations were confined to the presence of $24,25(\mathrm{OH})_{2} \mathrm{D},{ }^{17}{ }^{18}$ and, despite concern that other vitamin $\mathrm{D}$ metabolites (principally $25,26(\mathrm{OH})_{2} \mathrm{D}_{2}{ }^{19}$ and $25(\mathrm{OH}) \mathrm{D}_{3}$ 26,23 -lactone $\left.{ }^{20}\right)$ might interfere with the sensitive assay techniques, the results have been interpreted as indicating an extrarenal site of synthesis of $24,25(\mathrm{OH})_{2} \mathrm{D}$. Further studies from different laboratories have not only confirmed these data ${ }^{21}$ but have reported detectable concentrations of $1,25(\mathrm{OH})_{2} \mathrm{D}$ in sera from some anephric patients. ${ }^{22.24}$

The concentrations of the dihydroxylated metabolites detected are well below normal values and lie at the lower limits of the currently available assays. Moreover, most reported data concern measurement of total $1,25(\mathrm{OH})_{2} \mathrm{D}$ and not specifically the biologically active metabolite $1,25(\mathrm{OH})_{2} \mathrm{D}_{3}$. Nevertheless, though obtained from only a few patients, the results may indicate an extrarenal site of production for both $24,25(\mathrm{OH})_{2} \mathrm{D}_{3}$ and $1,25(\mathrm{OH})_{2} \mathrm{D}_{3}$. The origin of these metabolites is unknown, but both may be synthesised from $25(\mathrm{OH}) \mathrm{D}_{3}$ by bone cells in culture. ${ }^{25}$ It remains only to be determined whether such small quantities of active vitamin $\mathrm{D}$ metabolites help to prevent osteomalacia in some anephric patients.

Senior Lecturer in Medicine,

Graeme R D Catto

University of Aberdeen,

Aberdeen AB9 2ZB

Lecturer in Medicine,

NORMAN MUIRHEAD

University of Newcastle upon Tyne,

Newcastle upon Tyne NE1 7RU

1 Van Ypersele de Strihou C, Stragier A. Effect of bilateral nephrectomy on transfusion requirements of patients undergoing chronic dialysis. Lancet 1969;ii:705-7

De Luca HF. Vitamin D metabolism. Clin Endocrinol (Oxf) 1977;7(suppl):1-17.

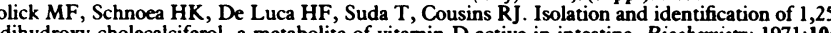
Biochemistry 1971;10:

Eastwood JB, Daly A, Carter GD, Alaghbank-Zadeh J, de Wardener HE. Plasma 25-hydroxy vitamin $\mathrm{D}$ in normal subjects and patients with terminal renal failure, on maintenance haemodialysis and after transplantation. Clin Sci 1979;57:473-6.
Fraser DR, Kodicek E. Unique biosynthesis by kidney of a biologically active vitamin D

metabolite. Nature 1970;228:764-6.

Gray R, Boyle I, De Luca HF. Vitamin D metabolism: the role of kidney tissue. Science 1971; 172:1232-4.

Ghazarian JG, De Luca HF. 25-Hydroxycholecalciferol-1-hydroxylase: a specific requirement for NADPH and a hemoprotein component in thick kidney mitochondria. Arch Biochem Biophys 1974;160:63-72.

De Luca HF. Recent advances in our understanding of the vitamin D endocrine system. $\boldsymbol{f}$ Lab

Clin Med 1976;87:7-26.
Haussler MR, McCain TA. Basic and clinical concepts related to vitamin D metabolism and action. N Engl f Med 1977;297:974-83.

nutson JC, De Luca HF. 25-hydroxy vitamin $\mathrm{D}_{3}$-24-hydroxylase. Subcellular location and properties. Biochemistry 1974;13:1543-8.
anaka Y, De Luca HF. The control

pe luca HF. The control of 25 -hydroxy vitamin D metabolism by inorganic phosphorus. Arch Biochem Biophys 1973;154:566-74.

parathyroid hormones and 25-hydroxy vitamin D in , Wergedal JE. Serum immunoreactive Endocrinol Metab 1975;40:1009-17.

Mason RD, Lissner D, Wilkinson M, Posen S. Vitamin D metabolites and their relationship to azotaemic osteodystrophy. Clin Endocrinol $(O \times f)$ 1980;13:375-85.

Juttman JR, Buurman CJ, Dekam E, Visser TJ, Birkenhager JC. Serum concentration of metabolites of vitamin $D$ in patients with chronic renal failure: consequences for the treatmen with la hydroxy-derivatives. Clin Endocrinol $(O x f)$ 1981;14:225-36.

Ritz E, Krempien B, Mehls O, Malluche HH. Skeletal abnormalities in chronic renal insufficiency before and during maintenance haemodialysis. Kidney Int 1974;3:116-27

Bordier PJ, Tun Chot S, Eastwood JB, Fournier A, de Wardener HW. Lack of histological evidence of vitamin D abnormality in the bones of anephric patients. Clin Sci 1973;44:33-41. , Horst RL, Hamstra A], De Luca HF. Determination of vitamin metabolites in plasma from normal and anephric man. Biochem $\mathcal{J}$ 1979;182:55-69.

等 of plasma levels of vitamin $D_{3}$ and five of its metabolites in normal
failure patients and anephric subjects. I Lab Clin Med 1981;98:536-48.

19 Taylor CM, Wallace JE, Cundy T, Kanis JA. Effects of vitamin $D_{2}$ on the assay of 24,25 dihydroxy vitamin $D_{3}$ in man. Mineral and Electrolyte Metabolism 1982;7:15-9.

${ }^{20}$ Horst RL. 25-OHD $-26,23$ lactone: a metabolite of vitamin $\mathrm{D}_{3}$ that is five times more potent than $25-\mathrm{OHD}_{3}$ in the rat plasma competitive protein binding radioassay. Biochem Biophys Res

21 Zerwekh JE, McPhaul JJ, Parker TF, Pak CYC. Extra-renal production of 24,25 dihydroxyvitamin $\mathrm{D}$ in chronic renal failure during 25-hydroxyvitamin $\mathrm{D}_{3}$ therapy. Kidney Int 1983;23:

Barbour GL, Coburn JW, Slatopolsky E, Norman AW, Horst RL. Hypercalcemia in an anephric patient with sarcoidosis: evidence for extrarenal generation N Engl f Med 1981;305:440-3.

列 dihydroxyvitamin $D$ in man. $\mathcal{J}$ Clin Invest $1982 ; 69: 722-5$.

ongen MJM, van der Viigh WJF, Lips P, Netelenbos JC. Measurement of vitamin D metabolites in anephric subjects. Nephron 1984;36:230-4.

${ }^{25}$ Howard GA, Turner RT, Sherrard DJ, Baylink DJ. Human bone cells in culture metabolize 25 -hydroxy vitamin $\mathrm{D}_{3}$ to 1,25 -dihydroxy and 24,25 -dihydroxyvitamin $\mathrm{D}_{3}$. $\mathrm{J}$ Biol Chem 1981;256:7738-40.

\section{Delayed psychological effects of perinatal deaths: the next pregnancy and the next generation}

Until about 15 years ago the psychological sequelae of stillbirth or neonatal death attracted few publications and were sadly neglected in clinical practice.' Recently, however, awareness of the psychological problems in the families concerned has increased. ${ }^{24}$

The mother of a stillborn baby feels bewildered and sad, and such feelings may develop into chronic depression, 
hypochondriasis, phobias, or other disturbances. ${ }^{5}$ All parents feel an irrational shame and guilt, and some of their immediate reactions may be a necessary part of normal mourning. In addition, less obvious secondary dangers need to be recognised ${ }^{6}$-for example, the father may be more affected than the mother and become overburdened by the expectation that he must be a support to his wife. Sexual pleasure may be destroyed and marriages ruined. The other children in the family may also be troubled by a perinatal death and there is long term risk that they will develop personality problems. Survivor guilt is one such problem, or the children may have an uncertain sense of identity owing to their parents' bewilderment and confused expectations. These children may carry problems into the next generation when they become parents themselves; the processes of childbirth have an uncanny way of reactivating the past.

Important problems may occur in the next pregnancy despite the joyful fulfilment that a healthy baby brings. ${ }^{6}$ Thus mothering difficulties are common and cause disappointment. Parents are puzzled by their mixed feelings towards the new baby. ${ }^{8}$ Unexpected puerperal reactions are often severe, and the danger seems to be greatest when the reactions to the previous perinatal death appeared minimal and another pregnancy follows quickly. The next baby is also at risk: he or she may develop personality problems as a "replacement child," whose identity is permanently confused with a different and dead baby.' Some unfortunate children are even given the name intended for the dead baby. This is something which should always be avoided.

Mourning is temporarily painful and may be disabling, but it is necessary for recovery from bereavement. Time and room are necessary, but often lacking, especially if the process is cut short by another pregnancy ${ }^{10}$ Factors that interfere with grasping the reality of what has happened will also impede mourning-for example, bewildering or ambiguous circumstances, anger and guilt, and the reactivation of previous loss. All these occur after a perinatal death, especially bewilderment, unreality, anger, and self reproach. Mourning is facilitated if the parents are encouraged to see and hold the dead baby, keep photographs, register a proper name, attend a funeral, and see that a proper grave is marked. ${ }^{11-17}$ Parents need support to avoid social isolation, and steps should be taken by counselling and attentive follow up. The Stillbirth and Neonatal Death Society (SANDS, Argyle House, 29-31 Euston Road, London NW1 1SD) promotes a network of self help groups and advice. Help in tracing unmarked graves is being requested with increasing frequency as parents realise the comfort that this may provide, even years after the event. A recent BBC television film on this topic evoked hundreds of letters and may be hired for teaching. ${ }^{18}$

Pregnancy should be postponed until the main mourning period has passed, for the mother cannot complete the mourning process when she becomes preoccupied with her growing baby and the impending birth. ${ }^{19}$ Of course, it is all too easy to be depressed in pregnancy, but depression is not the same as mourning. Normal mourning is a period of psychological disturbance, and it is hard to know when it becomes unhealthy. The intensity or rigidity of residual symptoms is more important than any specific feature in itself, and it may be too early for another pregnancy if either parent has persistent grievances or obvious psychiatric disability. Unrealistic idealisation of the dead baby and unrealistic hopes of the benefits from a new one are ominous signs. Normal sadness and pensiveness are reassuring.
During the next pregnancy counselling should come from those directly concerned with antenatal care. Patients are often guarded, hard to engage in formal psychotherapy, and may do better if members of the obstetric team themselves can listen and understand. Their sympathetic support helps patients to put together a conscious and more accurate awareness of their family histories (and myths) and the process of history taking helps to clarify the issues. It may be helpful to include the father and other children in these discussions. Genetic counselling and discussion of investigations give parents the opportunity to bring difficult feelings and irrational fears into the open. Continuity of care is also important, and reliable standards of continuity, warmth, and tact must be maintained-despite our overstretched obstetric service-for in these pregnancies better than average care is required. Flaws in the system, gaps in concern, and muddles and mistakes are disproportionately disturbing to these families.

Perinatal death affects the staff too: doctors have a tendency not to know, not to notice, and not to remember the clinical details of their patient..$^{20}$ Others, who are isolated in their domiciliary work-health visitors, for instance-may bear a crushing burden of gloom and anxiety. Two recent studies have attempted to evaluate the benefit of different managements (p 167). ${ }^{21}$ In both, the descriptive details are more striking than the statistics, but the figures expose the difficulty of maintaining contact with families who have sustained a perinatal death. In the Oxford study 40 from a series of 100 cases were lost after 14 months $^{21}$; in the Scottish study six of the 18 families were lost to follow up over a similar period. These figures come from teams who were actively attempting follow up and provide a measure of the best level of care; evidently, fracture of the doctor-patient relationship is hard to avoid. The human details are poignant: of seven Glasgow mothers who had not been offered a memento of their dead baby, two had taken something by stealth-a lock of hair and a name band.

STANFORD BOURNE Consultant psychotherapist

EManuel Lewis

Consultant psychotherapist

Perinatal Bereavement Unit,

Tavistock Clinic,

London NW3 5BA

1 Anonymous. The abhorrence of stillbirth [Editorial]. Lancet 1977;i:1188

Kirkley-Best E, Kellner KR. The forgotten grief: a review of the psychology of stillbirth. Am $\mathfrak{f}$

Orthopsychiat 1982;52:420-9.
ewis E. Stillbirth: psychological consequences and strategies of management. In: Milunsky A, ed. Advances in perinatal medicine. Vol 3. New York: Plenum, 1983:205-45.

4 Peppers LG, Knapp RJ. Motherhood and mourning. New York: Praeger, 1980 .
5 Cullberg J. Mental reactions of women to perinatal death. In: Morris N, ed. Psychosomatic medicine in obstetrics and gynaecology. Basle: Karger, 1972:326.

medicine in obstetrics and gynaecology. Basle: Karger, 1972:326.
${ }^{6}$ Bourne S, Lewis E. Pregnancy following a stillbirth or neonatal death: psychological risks and management. Lancet 1984 (in press).

Guyotat J. Mort naissance et filiation: etudes de psychopathologie sur le lien de filiation. Paris: Masson, 1980.

Lewis E, Page
$1978 ; 51: 237$.

Poznanski EO The "replacement child": a saga of unresolved parental grief. $\mathcal{I}$ Pediatr 1972;81:

1190 .

${ }^{1}$ Lewis E. Inhibition of mourning by pregnancy: psychopathology and management. Br Med $\mathcal{J}$ 1979;i: 27

Klaus MH, Kennell J. Caring for the parents of a stillborn or an infant who dies. Parent-infan bonding. St Louis: Mosby, 1982:259-92.

2 Bourne S. Psychological impact of stillbirth. Practitioner 1983;227:53-60.

${ }_{3}$ Lewis E. Mourning by the family after a stillbirth or neonatal death. Arch Dis Child 1979;54:303. Bourne S. Coping with perinatal death: management problems and strategies. Midwife Health Visitor Community Nurse 1979;15:89.

15 Giles PFH. Reactions of women to perinatal death. Aust NZ J Obstet Gynaecol 1970;10:207. orrest GC, Claridge RS, Baum JD. Practical management of perinatal death. Br Med $\mathcal{f} 1981$ 282:31.

17 Lewis E. Management of stillbirth-coping with an unreality. Lancet 1976;ii:619-20. C Tevision. Film: The Lost babies. 1983 November 9. (Available from Concord Film Council Ltd, 201 Felixstowe Road, Nacton, Ipswich, Suffolk.)
Lewis E. Two hidden predisposing factors in child abuse. Int 7 Child Abuse 1979.3.327.

20 Bourne $S$. The psychological effects of still birth on women and their doctors. $\mathcal{F} R$ Coll Gen Pract 1968;16:103.
Forrest $C G$.

counselling after perinatal bereavement. $B r \operatorname{Med} \mathcal{J}$ perinatal death: a study of support and 